\title{
Recent Increase in Mercury Sedimentation in a Forest Lake
} Attributable to Peatland Drainage

\section{Simola, $\mathrm{H}$.}

Springer Verlag

1982

Simola, H. and Lodenius, M. 1982. Recent Increase in Mercury Sedimentation in a Forest Lake Attributable to Peatland Drainage. Bulletin of Environmental Contamination and Toxicology 29: 298-305.

http://hdl.handle.net/1975/197

Downloaded from Helda, University of Helsinki institutional repository.

This is an electronic reprint of the original article.

This reprint may differ from the original in pagination and typographic detail.

Please cite the original version. 


\title{
Recent Increase in Mercury Sedimentation in a Forest Lake Attributable to Peatland Drainage
}

\author{
Heikki Simola' and Martin Lodenius ${ }^{2}$ \\ 1 Univ. Joensuu, Karelian Institute, Section of Ecology, P.O. Box 111, SF-80101 \\ Joensuu, Finland and 2 Univ. Helsinki, Department \\ of Environmental Science, SF-00710, Helsinki 71, Finland
}

\begin{abstract}
Observations of elevated mercury levels in the aquatic environment in the northern hemisphere have recently evoked much attention (e.g. KOIRTYOHANN et al. 1974, SHERBIN 1979, Anon. 1982). Long-range transport of atmospheric pollutants, acid precipitation and drainage measures have been mentioned as possible reasons. In many cases high $\mathrm{Hg}$ levels seem to occur consequent to extensive peat land drainage undertakings, but lack of appropriate monitoring data has prevented the verification of causality in this relation.

In order to gain information about the natural background levels and about the recent history of mercury in our waters, we determined mercury profiles in two lakes in which annually laminated sediment is deposited, and which differ from each other with respect to the history of land use in their drainage areas. Annual sediment laminations or varves allow a precise dating of the studied sequence, and their existence indicates undisturbed recording of the history of the environment.
\end{abstract}

\section{MATERIALS AND METHODS}

\section{Study sites}

Lake Polvijärvi is situated in the commune of Juuka in North Karelia and Lake Pääjärvi in the communes of Lammi and Koski in the province of Häme in South Finland. The lakes and their drainage areas are characterised in Table 1.

The proportion of cultivated land around L. Pääjärvi is fairly well representative for the whole southern Finland. The drainage basin of L. Polvijärvi, with its high percentage of peat land, should be typical for the poorly drained and scarcely populated water divide zones of the Finnish Lake District.

Bedrock in the drainage area of L. Päajärvi is mainly gneisses and granite. In the vicinity of the lake areas of granodiorite and amphibolite occur. Precambrian gneisses, striped with amphibolite zones, also prevail in the drainage area of $\mathrm{L}$. Polvijärvi, but some metamorphosed sedimentary rocks (quarzite scists, calc silicates, limestone and mica gneiss) occur in its southern part. 
Table 1. Characteristics of the Lakes Pääjärvi and Polvijärvi and their drainage areas.

\begin{tabular}{|c|c|c|}
\hline & PÄÄJÄRVI & POLVI JÄRVI \\
\hline position & $61^{\circ} 04^{\prime} \mathrm{N}, 25^{\circ} 08^{\prime} \mathrm{B}$ & $63^{\circ} 09^{\prime} \mathrm{N}, 28^{\circ} 58^{\prime} \mathrm{E}$ \\
\hline elevation, m a.s.t. & 103 & 170 \\
\hline area, $\mathbf{k m}^{2}$ & 13.42 & 1.83 \\
\hline $\max \cdot \operatorname{depth}, \mathrm{m}$ & 87 & 35 \\
\hline mean depth, m & 14.4 & 5.1 \\
\hline volume, $10^{6} \mathrm{~m}^{3}$ & 205.7 & 9.3 \\
\hline theor. retention time, $\mathrm{d}$ & 1200 & 170 \\
\hline $\begin{array}{l}\text { drainage area, } \mathrm{km}^{2} \\
\text { of which: } \\
\text { other lakes } \\
\text { peatland } \\
\text { arable fields }\end{array}$ & $\begin{array}{r}244 \\
7.2 \% \\
10.6 \% \\
18.3 \%\end{array}$ & $\begin{array}{r}65 \\
9.2 \% \\
34.6 \% \\
2.0 \%\end{array}$ \\
\hline
\end{tabular}

The laminated sediment of Lake Polvijärvi incorporates a history of rapid eutrophication of the lake during the 1970's, which evidently is due to extensive peatland drainage and fertilization in its drainage area (SIMOLA submitted). Nearly $80 \%$ of the $22.5 \mathrm{~km}^{2}$ peatland area has been drained for forestry since the year 1960 , and $10.8 \mathrm{~km}^{2}$ of ditched peatlands were fertilized with phosphorus-potassium fertilizer in 1971.

The ecosystem of Lake Pääjärvi has been extensively studied during the past decade (e.8. RUUHIJÄRVI 1974, SARVALA et al. 1981). The lake is considered to be near its natural oligotrophic state still, although signs of moderate eutrophication, mainly due to agricultural effluents, are apparent in its shallow bays:.

Sampling

Two sediment cores were taken at each lake: one with the in situ -freezer of HUTTUNEN \& MERILÄINEN (1978) and the other with a Kajak-type gravity corer. The Kajak cores were sliced from the sediment-water contact downwards for determination of the profiles of water content, dry matter and organic matter. Chronology for these profiles (in calendar years prior to the sampling date) was established through the sediment laminations, that were analyzed in the frozen cores ( $F$ ig.1.).

Lake Polvijärvi was sampled in May 1981. The Kajak core was sliced into 10 successive subsamples, varying between 0.9 and 2.6 $\mathrm{cm}$ in thickness (the accurate height of each slice was determined by dividing its fresh volume with the core cross-section; $43.0 \mathrm{~cm}^{2}$ ). 

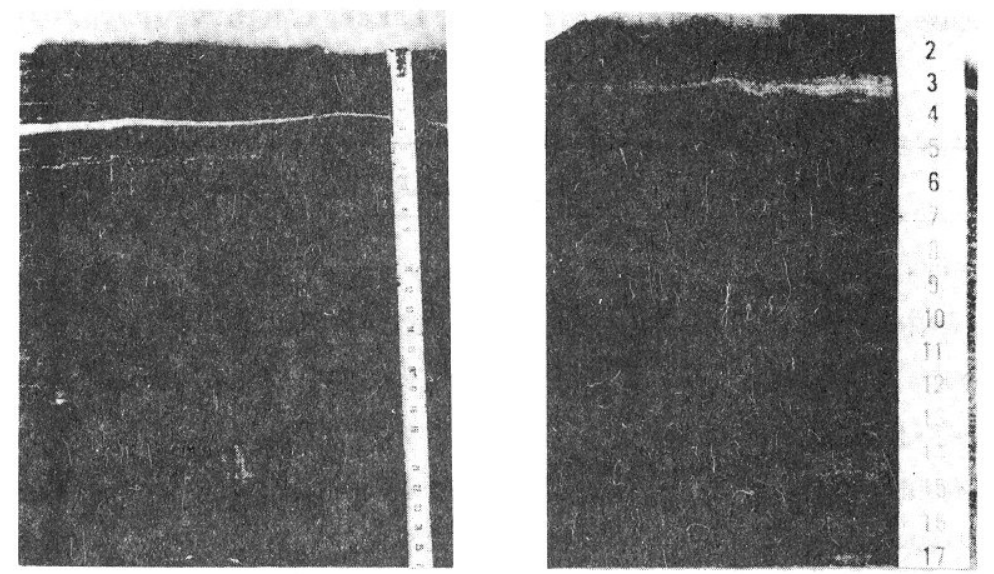

Figure 1. Laminated sediment of L. Polvijärvi (left) and L. Pääjärvi (right). The annual character of the laminations has been verified microscopically by SIMOLA (submitted) and SIMOLA \& UIMONEN-SIMOLA (1983). ${ }^{210} \mathrm{~Pb}$-dating has further confirmed the annuality of the laminations of L. Pääjärvi (APPLEBY et al. 1979). The recent eutrophication of L. Polvijärvi is reflected in the sediment as an abrupt increase in the thickness of the laminations (above $5 \mathrm{~cm}$ depth).

The lower end of this profile is at $17.5 \mathrm{~cm}$ and according to laminae counting the core represents the period 1864-1981. Subsamples for $\mathrm{Hg}$ determination were taken of these slices after they had been dried to constant weight in $+50^{\circ} \mathrm{C}$.

The samples of Lake Pääjärvi were taken at $55 \mathrm{~m}$ water depth in October 1979. The Kajak core $(0-21 \mathrm{~cm})$ was dissected into 0.5 $\mathrm{cm}$ thick slices, of which fresh weight, dry weight and loss-onignition were determined. Mercury concentrations were determined in 16 successive subsamples of the frozen core that were cut along the yearly boundaries. This sample sequence spanned the period 1873-1979 (a $3 \mathrm{~cm}$ thick turbid layer below the 1908 laminations was omitted from the chronology and from the samples). The dry matter and mercury quantities in the subsamples were transformed into fluxes through matching them with corresponding levels in the fresh and dry weight profiles of the Kajak core.

Mercury concentration were determined using cold vapour AAS after a wet combustion according to KIVALO et al. (1974) but using $10 \mathrm{ml}$ of acids for each sample.

\section{RESULTS}

\section{Polvijärvi}

At the lower part of the profile analyzed in Lake Polvijärvi (1864-1920 according to varve chronology), Hg concentration is 


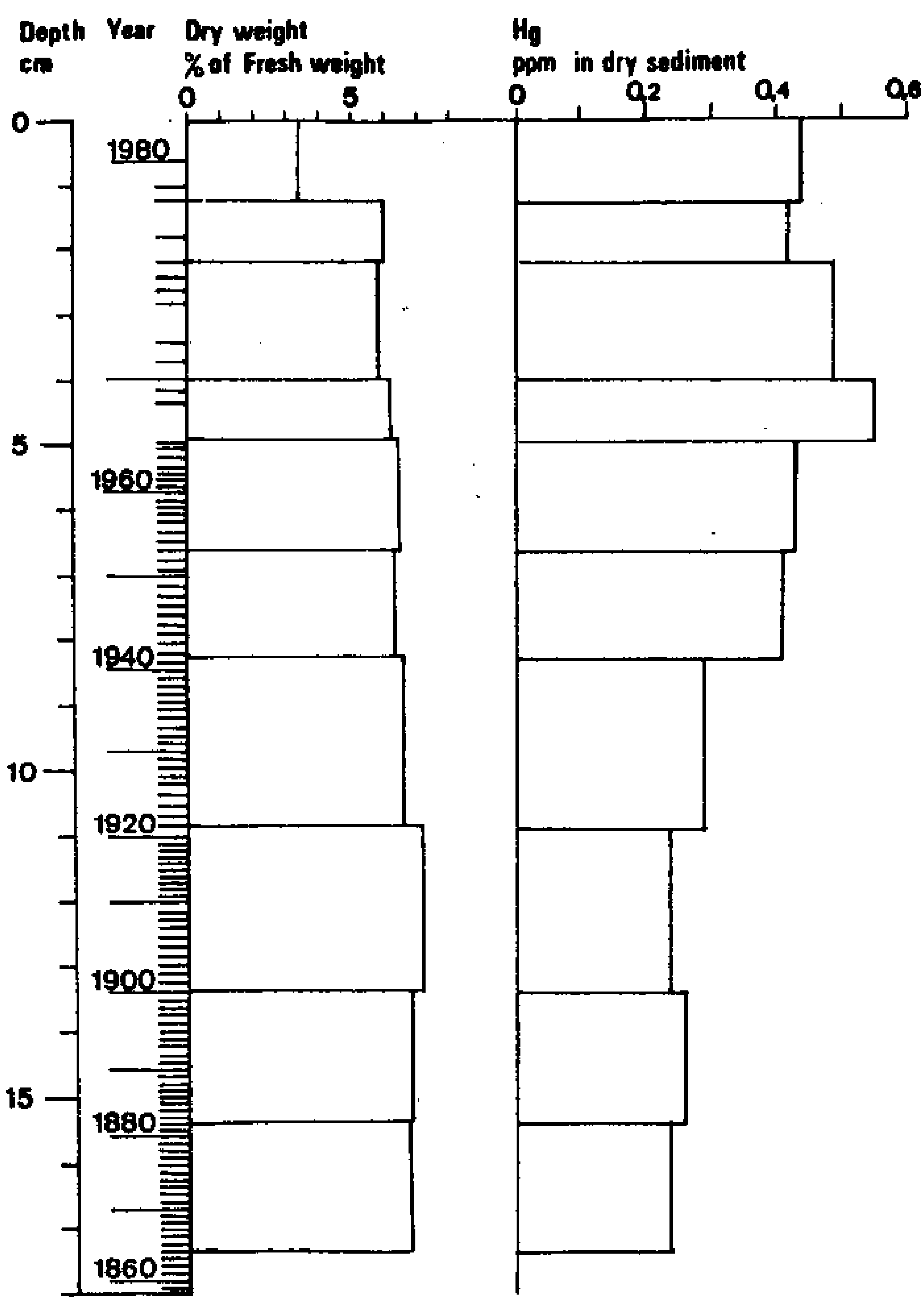

Figure 2. Dry weight and mercury profiles in the surface sediment at $35 \mathrm{~m}$ depth in L. Polvijärvi. Choronology according to sediment varves.

rather steadily $0.25 \mu \mathrm{g} \mathrm{g}^{-1}(\mathrm{ppm})$ in dry sediment. From this background value the concentration rises to an about doubled level in the samples representing the period 1967-1975 (Fig.2.). In the two uppermost slices (1976-1980), the concentration is only slightly lowered.

The gradual increase in the $\mathrm{Hg}$ concentration is superimposed with a rapid increase of the sediment accumulation rate that started in the late 1960 's. For this reason, the flux of $\mathrm{Hg}$ into the sediment in the period 1967-1977 has been about $f$ ive times higher than that at the end of the 19th century (Fig.3.).

The first rise in the concentration and in the accumulation rate of mercury is apparent in the slice representing the period 1942-1952. Tentatively, we relate this increase with the clearance of some small fields on the NW shore of the lake (partly on mineral slopes, partly on peatland) that took place during this period (mr. A. Nykänen, pers. comm.).

The recently increased sedimentation of $\mathrm{Hg}$ seems to have occurred in close correlation with the progress of the drainage undertakings (Fig.3.). Mobilization of soil mercury seems, indeed, the most plausible explanation for the observed increase, as industrial or agricultural emissions should not have been of any significance in the area. 


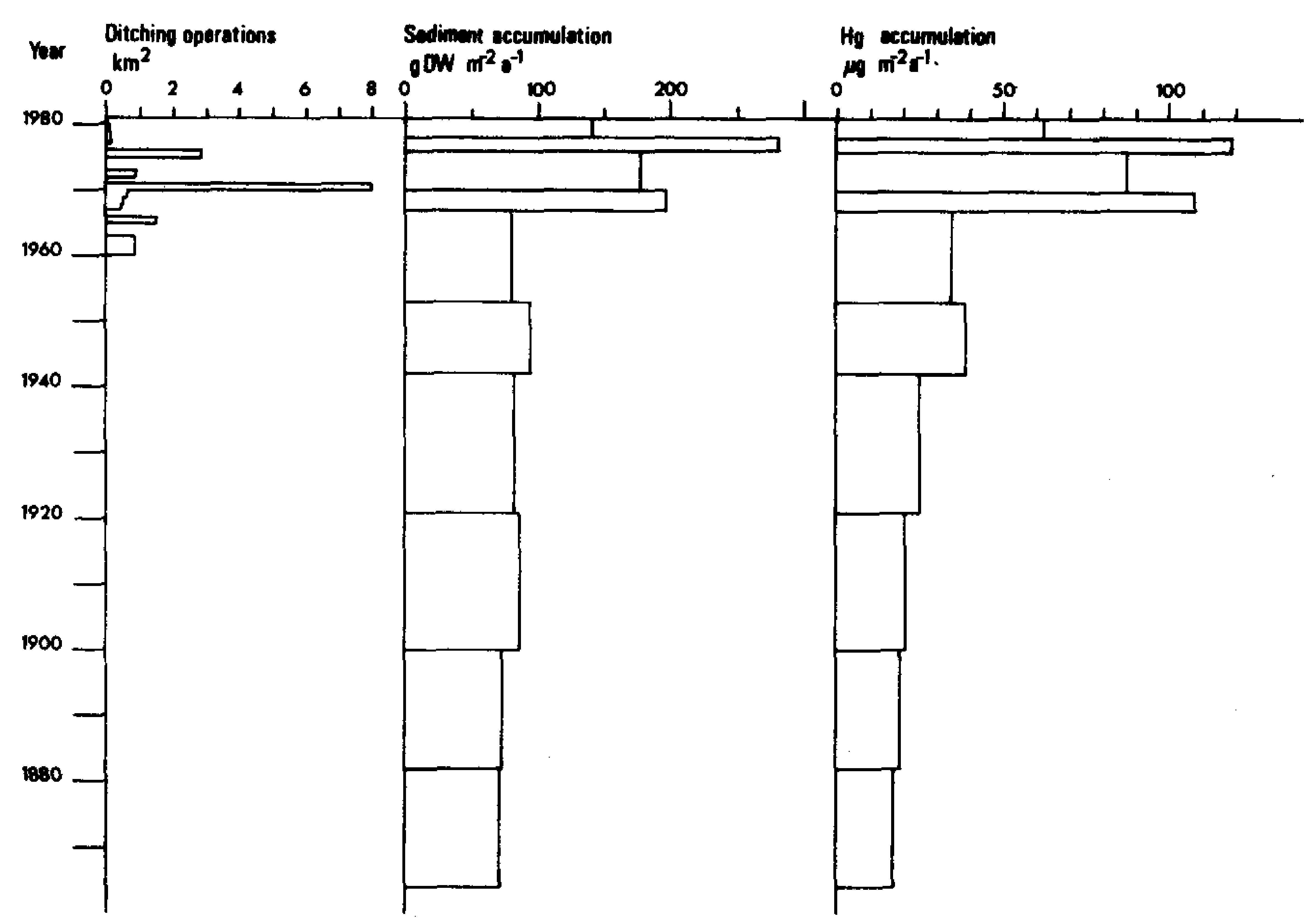

Figure 3. Ditchings of virgin peatlands in the drainage area and accumulation of sediment dry matter and mercury in $L$. Polvijärvi

\section{Pääjärvi}

Mercury concentrations in the samples of $L$. Pääjärvi are between 0.032 and $0.088 \mu \mathrm{g} \mathrm{g}$ in dry sediment, or much lower than in L. Polvijärvi. However, due to considerably higher accumulation rate of the (more minerogenic) sediment, the sedimentary flux of $\mathrm{Hg}$ in L. Pääjärvi is of the same magnitude as it was in L. Polvijärvi prior to the recent increase (Fig.4.). There is no clear trend in the $\mathrm{Hg}$ accumulation profile in L. Pääjärvi; part of the variation between successive samples seems merely to reflect lack of precision in the sediment accumulation rate determination.

In 1960 the water level of L. Pääjärvi was lowered by about $1 \mathrm{~m}$, which, together with the drainage of peatlands, seems to have caused increased mineral sedimentation in the profundal area during the 1960's. Mercury does not seem to have been excessively mobilised during this period.

\section{DISCUSSION}

The mercury content of Finnish soil and peat is around 0.1 the mercury is to a great extent bound to the organic matter, especially at low pH-values. At changing conditions the organic 


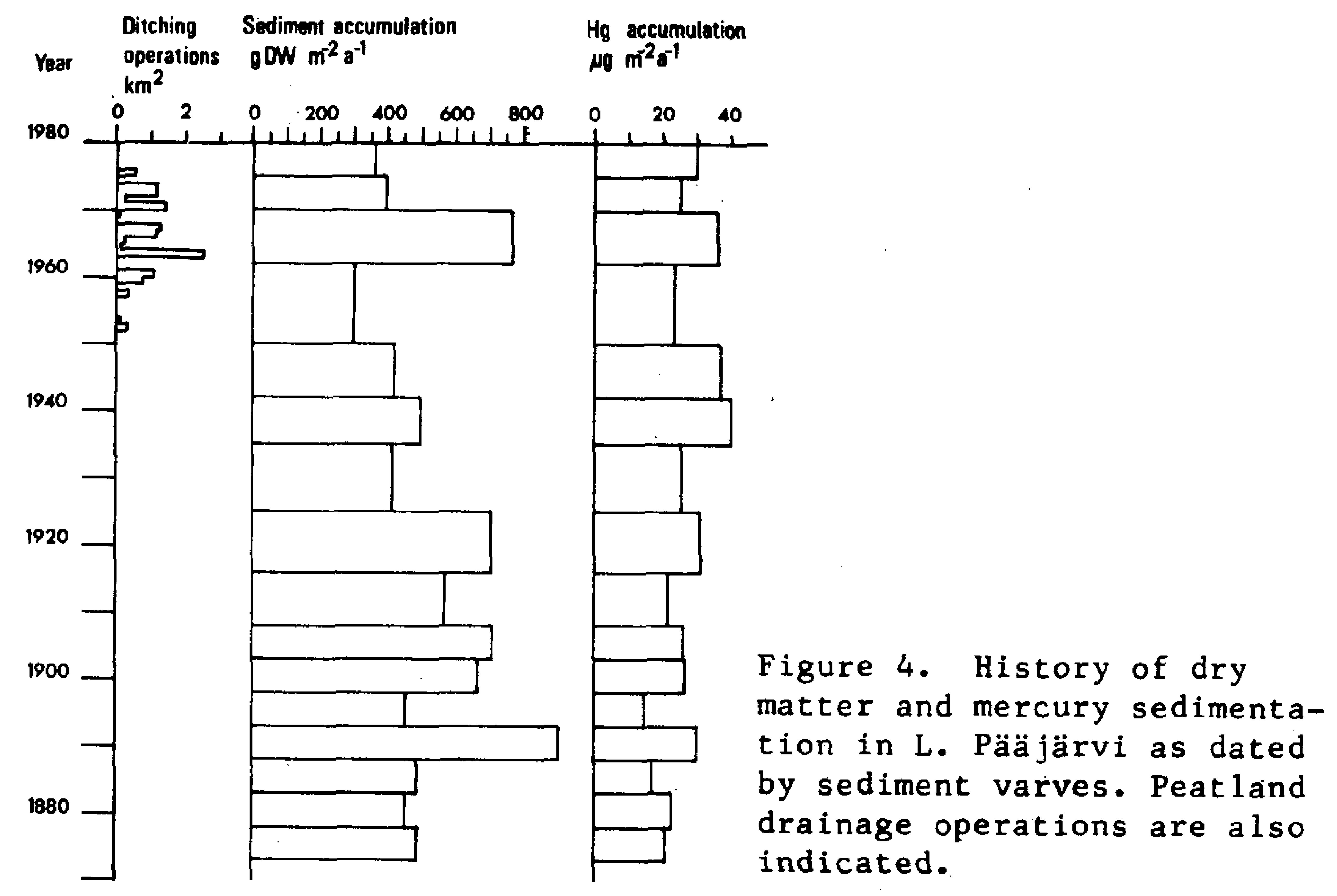

components including the complexed mercury may pass into solution (ANDERSSON 1979).

Mercury may be released from the soil and accumulated in aquatic food-chains after the construction of man-made lakes (e.g. ABERNATHY \& CUMBIE 1977, VERTA 1981, LODENIUS et al. 1982). Mercury forms readily complexes with humic substances (STROHAL \& HULJEV 1971, MILLER 1975, BENES et al. 1976) and the fulvic acids have been shown to increase the solubility of mercury (SCHNITZER \& KEREDORFF 1981). It has also been shown that the mercuric ign $\left(\mathrm{Hg}^{2+}\right.$ ) in sediments may be reduced to elemental mercury ( $\mathrm{Hg}^{8}$ ) in the presence of humic acid and thus released back into the water phase (ALBERTS et al. 1974, MILLER 1975). Much less mercury was by this way released by whole sediments than by purified humic acids (MILLER 1975) indicating the essential role of humic substances in the movements of mercury between water and sediments. Fulvic acids may also promote the methylation of mercury in soils (ROGERS 1977).

The background mercury levels in the sediments $\rho f$ the three largest Swedish lakes are $0.030,0.040$ and $0.095 \mu \mathrm{g} \mathrm{g}^{-1}$ respectively (HAKANSSON 1977). Also in Finland the background values are at the same level (SÄRKKÄ et al. 1978, HÄKKILÄ 1980, LODENIUS 1980). The mercury concentration in the sediment of Lake Pääarvi is in good agreement with these. The higher base level concentration in sediment of Lake Polvijärvi (about $0.25 \mu \mathrm{g} \mathrm{g}^{-1}$ ) is obviously consequent to the low mineral content. In fact, when calculated on the basisv of sedimentary organic matter the concentrations appear equivalent: in L. Pääjärvi the range is 0.41 to $0.73 \mu \mathrm{g} \mathrm{gOM}^{-1}$, and in L. Polvijärvi the pre-1920 concentration level is about $0.50 \mu \mathrm{g} \mathrm{gOM}^{-1}$. 
The anthropogenic emissions of mercury to the atmosphere seem to be much greater than the natural ones (LANTZY \& MACKENZIE 1979) and an increasing deposition of this metal has been observed in Danish bogs since approximately 1850 (MADSEN 1981). As no clear increase in the mercury sedimentation was observed in Lake Pääjärvi and the elevated concentrations of Lake Polvijärvi were closely related to the drainage undertakings, the influence of atmospheric deposition must be considered negligible in these two lakes.

In Finland about $55000 \mathrm{~km}^{2}$ of peatland has already been drained, which corresponds to $16 \%$ of the whole country. As a consequence of the abudance of peatlands the Finnish lakes are in general polyhumic (average $13 \mathrm{mg}$ humic matter $1^{-1}$ ) and the artificial drainage of forests and bogs as well as the regulation of waters may strongly increase the organic matter content in the lake water (HEIKURAINEN et al. 1978, KENTTÄMIES 1980). This may be one explanation for the high mercury concentrations found in many unpolluted lakes.

\section{ACKNOWLEDGEMENTS}

We thank Anne Ryynänen and Jukka Viipuri for technical assistance and Lilsa Koistinen for typing the text. This study was financially supported by Maj and Tor Nessling Foundation and the Academy of Finland.

\section{REFERENCES}

ABERNATHY, A.R. and P.M. CUMBIE: Bull. Environm. Contam. Toxicol. 17,595 (1977).

ALBERTS, J., J. SCHINDLER, R. MILLER and D. NUTTER: Science 184 , 895 (1974).

ANDERSSON, A.: Mercury in soils. In: NRIAGU, J.0. (ed.): The biogeochemistry of mercury in the environment. Amsterdam, New York, Oxford. (1979).

ANON.: Mil jöaktuellt 10 (1), 1 (1982).

APPLEBY, P.G., F. OLDFIELD, R. THOMPSON, P. HUTTUNEN and $K$. TOLONEN: Nature 280, 53 (1979).

BENEŠ, P., E.T. GJESSING and E. STEINNES: Water Res. 10, 711 (1976). BYSIEK, M., R. OERTLI, L. SALONEN and J.K. MIETTINEN: Proc. Internat. Peat Conf., June 1972, Helsinki (1972).

HÅKANSON , L.: Svenska Naturvàrdsverkets Promemoria 839 (1977). HÄKKILÄ, K.: Nat. Bd. Waters, Finland. Report $190\left(1 \frac{980}{980}\right)$. HEIKURAINEN, L., K. KENTTÄMIES and J. LAINE: Suo 29, 49 (1978). HUTTUNEN, P. and J. MERILÄINEN: Ann. Bot. Fennici 15, 128 (1978). KENTTÄMIES, K.: Publ. Water Res. Inst., Nat. Bd. Waters, Finland 39 , 13 (1980).

KIVALO, P., A. VISAPÄÄ and R. BÄCKMAN: Ana 1. Chem. 46, 1814 (1974). KOIRTYOHANN, S.R., R. MEERS and L.K. GRAHAM: Environm. Res. 8,1 (1974 LANTZY, R.J. and F.T. MacKENZIE: Geochim. Cosmochim. Acta 43, 511(197s LODENIUS, M.: Ann. Bot. Fennici 17, 336 (1980).

LODENIUS, M., A. SEPPÄNEN and M. HERRANEN: Accumulation of mercury in fish and man from reservoirs in northern Finland. Water, Air, Soil Pollut. (in press). 
MADSEN, P.P.: Nature 293, 127 (1981).

MILLER, R.W.: Verh. Internat. Ver. Limnol. 19, 2082 (1975).

RUUHIJÄRVI, R. : Ann. Bot. Fennici 11, 95 (1974).

ROGERS, R.D.: J. Environm. Qual. 6, 463 (1977).

SÄRKKÄ, J., M-L. HATTULA, J. JANATUINEN and J. PAASIVIRTA: Bull. Environm. Contam. Toxicol. 20, 332 (1978).

SARVALA, J., V. ILMAVIRTA, L. PAASIVIRTA and K. SALONEN: Verh. Internat. Verein. Limnol. 21, 454 (1981).

SCHNITZER, M. and H. KERNDORFF: Water, Air, Soil Pollut. 15, 97 (1981).

SHERBIN, I.G.: Mercury in the Canadian Environment. Report EPS 3-EC-79-6, Environment Canada (1979).

SIMOLA, H.: Limnological effects of peatland drainage and fertilization as reflected in the varved sediment of a deep lake. Manuscript (submitted; 1982).

SIMOLA, H. and P. UIMONEN-SIMOLA: Developments in Hydrobiology (in print; 1983).

SOVERI, J.: Ympäristö ja terveys 8,118 (1977).

STROHAL, P. and D. HULJEV: Investigation of mercury-pollutant interaction with humic acids by means of radiotracers. Nucl. Techniques in Environ. Pollut., IAEA, Vienna, 439 (1971).

VERTA, M.: Nat. Bd. Waters, Finland. Report 212, 45 (1981).

Accepted June 19, 1982 